Erratum

\title{
Erratum: Li, D.; Scarano, S.; Lisi, S.; Palladino, P.; Minunni, M. Real-Time Tau Protein Detection by Sandwich-Based Piezoelectric Biosensing: Exploring Tubulin as a Mass Enhancer. Sensors 2018, 18, 946
}

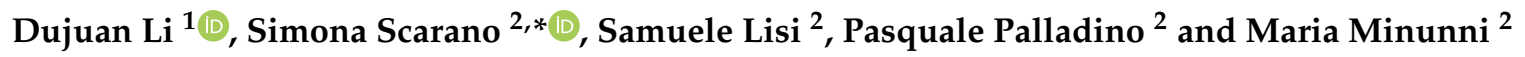 \\ 1 College of Life Information Science \& Instrument Engineering, Hangzhou Dianzi University, 115 Wenyi Rd, \\ Hangzhou 310000, China; dujuanli2015@outlook.com \\ 2 Department of Chemistry "Ugo Schiff", University of Florence, via della Lastruccia 3-13, Sesto Fiorentino, \\ 50019 Firenze, Italy; samuele.lisi@outlook.com (S.L.); pasquale.palladino@unifi.it (P.P.); \\ maria.minunni@unifi.it (M.M.) \\ * Correspondence: simona.scarano@unifi.it; Tel.: +39-054-573-283
}

Received: 8 March 2019; Accepted: 13 March 2019; Published: 22 March 2019

check for updates

The authors wish to make the following erratum to this paper [1]:

There is one mistake in this article [1]. On page 9, there is correction needed in reference [14]:

"Lisi, S.; Scarano, S.; Fedeli, S.; Cicchi, S.; Pascale, E.; Ravelet, C.; Peyrin, E.; Minunni, M. Toward sensitive immuno-based detection of tau protein by surface plasmon resonance coupled to carbon nanostructures as signal amplifiers. Biosens. Bioelectron. 2016, 85, 83-89."

This should be replaced with:

“Lisi, S., Scarano, S., Fedeli, S., Pascale, E., Cicchi, S., Ravelet, C., Peyrin, E.; Minunni, M. Toward sensitive immuno-based detection of tau protein by surface plasmon resonance coupled to carbon nanostructures as signal amplifiers. Biosens. Bioelectron. 2017, 93, 289-292."

The authors would like to apologize for any inconvenience caused to the readers by these changes.

\section{References}

1. Li, D.; Scarano, S.; Lisi, S.; Palladino, P.; Minunni, M. Real-Time Tau Protein Detection by Sandwich-Based Piezoelectric Biosensing: Exploring Tubulin as a Mass Enhancer. Sensors 2018, 18, 946. [CrossRef] [PubMed]

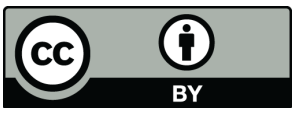

(C) 2019 by the authors. Licensee MDPI, Basel, Switzerland. This article is an open access article distributed under the terms and conditions of the Creative Commons Attribution (CC BY) license (http://creativecommons.org/licenses/by/4.0/). 